\title{
LEVEL II SCOUR ANALYSIS FOR BRIDGE 25 (HARDTH00420025) on TOWN HIGHWAY 42, crossing LAMOILLE RIVER, HARDWICK, VERMONT
}

U.S. Geological Survey Open-File Report 96-231

Prepared in cooperation with

VERMONT AGENCY OF TRANSPORTATION and

FEDERAL HIGHWAY ADMINISTRATION 


\section{LEVEL II SCOUR ANALYSIS FOR BRIDGE 25 (HARDTH00420025) on TOWN HIGHWAY 42, crossing LAMOILLE RIVER, HARDWICK, VERMONT \\ By JOSEPH D. AYOTTE}

U.S. Geological Survey Open-File Report 96-231

Prepared in cooperation with

VERMONT AGENCY OF TRANSPORTATION and

FEDERAL HIGHWAY ADMINISTRATION 


\title{
U.S. DEPARTMENT OF THE INTERIOR BRUCE BABBITT, Secretary
}

\author{
U.S. GEOLOGICAL SURVEY \\ Gordon P. Eaton, Director
}

For additional information write to:

District Chief

U.S. Geological Survey 361 Commerce Way

Pembroke, NH 03275
Copies of this report may be purchased from:

U.S. Geological Survey Earth Science Information Center Open-File Reports Section Box 25286, MS 517 Federal Center

Denver, CO 80225 


\section{CONTENTS}

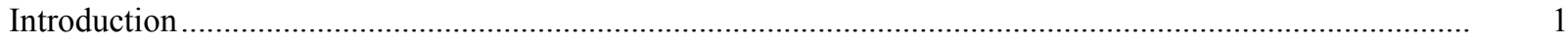

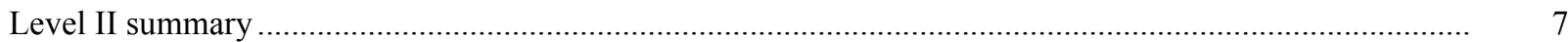

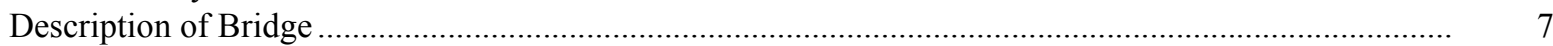

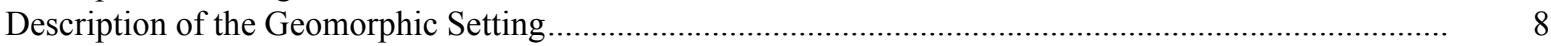

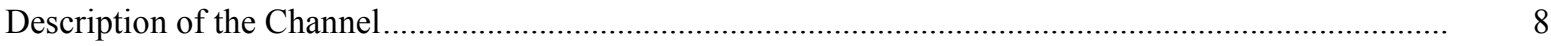

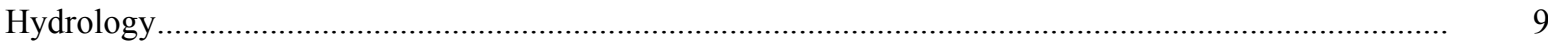

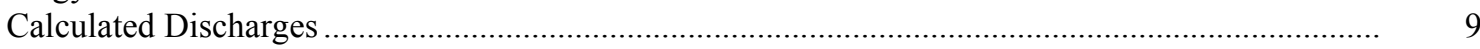

Description of the Water-Surface Profile Model (WSPRO) Analysis ......................................................... 10

Cross-Sections Used in WSPRO Analysis ......................................................................................

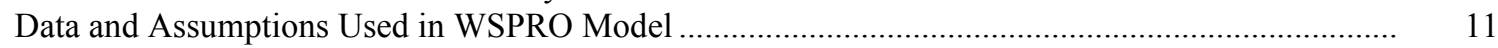

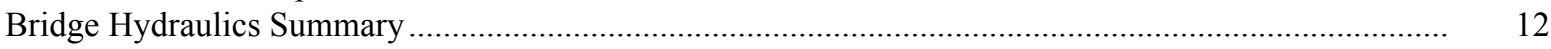

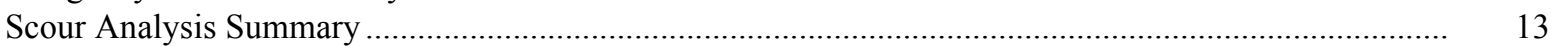

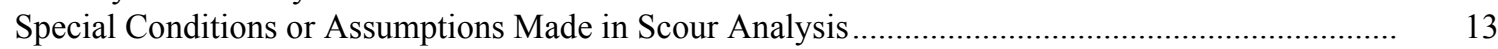

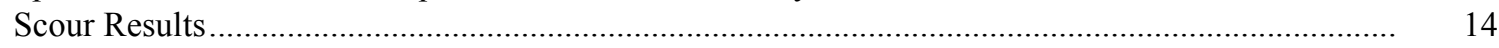

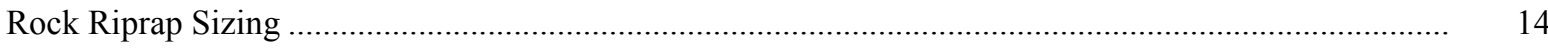

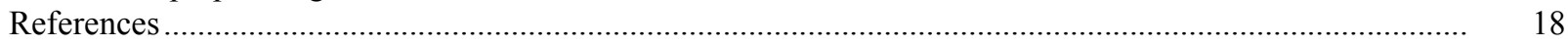

Appendixes:

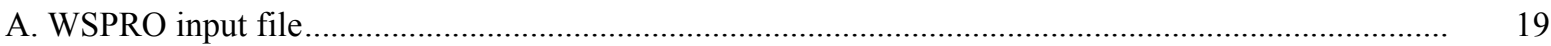

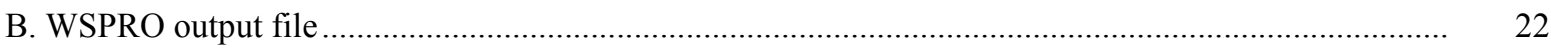

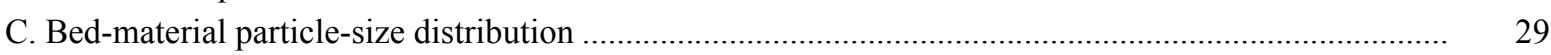

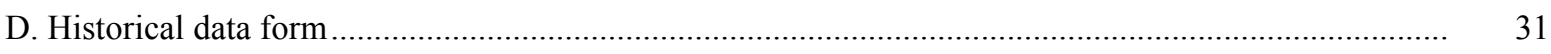

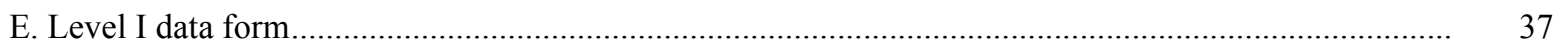

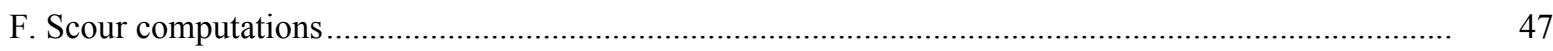

G.Post August 5-6, 1995 flood Level I and II data for structure HARDTH00420025 .............................. 51

\section{FIGURES}

1. Map showing location of study area on USGS 1:24,000 scale map ........................................................

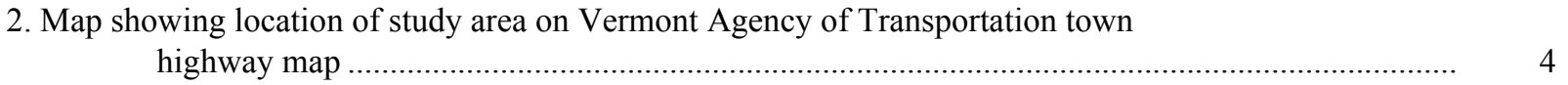

3. Structure HARDTH00420025 viewed from upstream (July 25, 1995) ……………...............................

4. Downstream channel viewed from structure HARDTH00420025 (July 25, 1995). .................................. 5

5. Upstream channel viewed from structure HARDTH00420025 (July 25, 1995) ....................................... 6

6. Structure HARDTH00420025 viewed from downstream (July 25, 1995), .................................................. 6

7. Water-surface profiles for the 100- and 500-year discharges at structure

HARDTH00420025 on Town Highway 42, crossing Lamoille River, Hardwick, Vermont.

8. Scour elevations for the 100- and 500-year discharges at structure

HARDTH00420025 on Town Highway 42, crossing Lamoille River,

Hardwick, Vermont.

\section{TABLES}

1. Remaining footing/pile depth at abutments for the 100-year discharge at structure

HARDTH00420025 on Town Highway 42, crossing Lamoille River,

Hardwick, Vermont.

2. Remaining footing/pile depth at abutments for the 500-year discharge at structure

HARDTH00420025 on Town Highway 42, crossing Lamoille River,

Hardwick, Vermont. 


\begin{tabular}{|c|c|c|}
\hline Multiply & By & To obtain \\
\hline \multicolumn{3}{|c|}{ Length } \\
\hline inch (in.) & 25.4 & millimeter (mm) \\
\hline foot $(\mathrm{ft})$ & 0.3048 & meter $(\mathrm{m})$ \\
\hline mile (mi) & 1.609 & kilometer (km) \\
\hline \multicolumn{3}{|c|}{ Slope } \\
\hline foot per mile ( $\mathrm{ft} / \mathrm{mi})$ & 0.1894 & meter per kilometer $(\mathrm{m} / \mathrm{km})$ \\
\hline \multicolumn{3}{|c|}{ Area } \\
\hline square mile $\left(\mathrm{mi}^{2}\right)$ & 2.590 & square kilometer $\left(\mathrm{km}^{2}\right)$ \\
\hline \multicolumn{3}{|c|}{ Volume } \\
\hline cubic foot $\left(\mathrm{ft}^{3}\right)$ & $\begin{array}{l}0.02832 \\
\text { Velocity and Flow }\end{array}$ & cubic meter $\left(\mathrm{m}^{3}\right)$ \\
\hline foot per second (ft/s) & 0.3048 & meter per second $(\mathrm{m} / \mathrm{s})$ \\
\hline cubic foot per second $\left(\mathrm{ft}^{3} / \mathrm{s}\right)$ & 0.02832 & cubic meter per second $\left(\mathrm{m}^{3} / \mathrm{s}\right)$ \\
\hline $\begin{array}{l}\text { cubic foot per second per } \\
\text { square mile } \\
{\left[\left(\mathrm{ft}^{3} / \mathrm{s}\right) / \mathrm{mi}^{2}\right]}\end{array}$ & 0.01093 & $\begin{array}{l}\text { cubic meter per } \\
\text { second per square } \\
\text { kilometer }\left[\left(\mathrm{m}^{3} / \mathrm{s}\right) / \mathrm{km}^{2}\right]\end{array}$ \\
\hline
\end{tabular}

OTHER ABBREVIATIONS

$\begin{array}{lrlr}\mathrm{BF} & \text { bank full } & \text { LWW } & \text { left wingwall } \\ \mathrm{cfs} & \text { cubic feet per second } & \text { MC } & \text { main channel } \\ \mathrm{D}_{50} & \text { median diameter of bed material } & \text { RAB } & \text { right abutment } \\ \mathrm{DS} & \text { downstream } & \text { RABUT } & \text { face of right abutment } \\ \mathrm{elev} & \text { elevation } & \text { RB } & \text { right bank } \\ \mathrm{f} / \mathrm{p} & \text { flood plain } & \text { ROB } & \text { right overbank } \\ \mathrm{ft} & \text { square feet } & \text { RWW } & \text { right wingwall } \\ \mathrm{ft} / \mathrm{ft} & \text { feet per foot } & \text { TH } & \text { town highway } \\ \mathrm{JCT} & \text { junction } & \text { UB } & \text { under bridge } \\ \mathrm{LAB} & \text { left abutment } & \text { US } & \text { upstream } \\ \mathrm{LABUT} & \text { face of left abutment } & \text { USGS } & \text { United States Geological Survey } \\ \text { LB } & \text { left bank } & \text { VTAOT Vermont Agency of Transportation } \\ \text { LOB } & \text { left overbank } & \text { WSPRO } & \text { water-surface profile model }\end{array}$

In this report, the words "right" and "left" refer to directions that would be reported by an observer facing downstream. Sea level: In this report, "sea level" refers to the National Geodetic Vertical Datum of 1929-- a geodetic datum derived from a general adjustment of the first-order level nets of the United States and Canada, formerly called Sea Level Datum of 1929.

In the appendices, the above abbreviations may be combined. For example, USLB would represent upstream left bank. 


\title{
LEVEL II SCOUR ANALYSIS FOR BRIDGE 25 (HARDTH00420025) ON TOWN HIGHWAY 42, CROSSING LAMOILLE RIVER, HARDWICK, VERMONT
}

\author{
By Joseph D. Ayotte
}

\section{INTRODUCTION}

This report provides the results of a detailed Level II analysis of scour potential at structure HARDTH00420025 on town highway 42 crossing the Lamoille River, Hardwick, Vermont (figures 1-8). A Level II study is a basic engineering analysis of the site, including a quantitative analysis of stream stability and scour (U.S. Department of Transportation, 1993). A Level I study is included in Appendix E of this report. A Level I study provides a qualitative geomorphic characterization of the study site. Information on the bridge available from VTAOT files was compiled prior to conducting Level I and Level II analyses and can be found in Appendix D.

The site is in the Green Mountain physiographic division of north-central Vermont in the town of Hardwick. The $119-\mathrm{mi}^{2}$ drainage area is in a predominantly rural basin. In the vicinity of the study site, the left banks are covered by pasture and (or) fields. The right bank of Lamoille River is adjacent to Vermont Route 15 near the north edge of the Lamoille River valley

In the study area, the Lamoille River has a sinuous channel with a slope of approximately $0.0004 \mathrm{ft} / \mathrm{ft}$, an average channel top width of $89.0 \mathrm{ft}$ and an average channel depth of $8.0 \mathrm{ft}$. The predominant channel bed material is sand and gravel $\left(\mathrm{D}_{50}\right.$ is $22.4 \mathrm{~mm}$ or $\left.0.0733 \mathrm{ft}\right)$. In general, the banks have sparse or no woody vegetative cover and the reach was noted to be laterally unstable at the time of the Level I site visit on July 25, 1995. The Level II work was completed on 07/27/95 and the site was revisited on August 16, 1995, just after the August 5-6, 1995 flood on the Lamoille River. Findings from this follow-up visit are presented in Appendix G.

The town highway 42 crossing of the Lamoille River is a 62-ft-long, two-lane bridge consisting of one 60-foot steel- beam span with a concrete deck, supported by vertical abutments with wingwalls on upstream and downstream sides (Vermont Agency of Transportation, written commun., August 24, 1994). The bridge is supported by vertical abutments with wingwalls on upstream and downstream sides. The channel is not skewed to the opening and the opening-skew-to-roadway is 0 degrees. 
A scour hole $3.0 \mathrm{ft}$ deeper than the mean thalweg depth was observed 5 feet upstream from the bridge face at mid-channel during the Level I assessment. Additional details describing conditions at the site are included in the Level II Summary and Appendices D and E.

Scour depths and rock rip-rap sizes were computed using the general guidelines described in Hydraulic Engineering Circular 18 (Richardson and others, 1993).

Total scour at a highway crossing is comprised of three components: 1) long-term aggradation or degradation; 2) contraction scour (due to reduction in flow area caused by a bridge) and; 3) local scour (caused by accelerated flow around piers and abutments). Total scour is the sum of the three components. Equations are available to compute scour depths for contraction and local scour and a summary of the results follows.

Contraction scour for all modelled flows was $0.0 \mathrm{ft}$. Abutment scour ranged from $6.5 \mathrm{ft}$ to $15.6 \mathrm{ft}$ and the worst-case abutment scour occurred at the 500-year discharge. Scour depths and depths to armoring are summarized on p. 14 in the section titled "Scour Results". Scour elevations, based on the calculated depths are presented in tables 1 and 2; a graph of the scour elevations is presented in figure 8 Scour depths were calculated assuming an infinite depth of erosive material and a homogeneous particle-size distribution.

For all scour presented in this report, "the scour depths adopted [by VTAOT] may differ from the equation values based on engineering judgement" (Richardson and others, 1993, p. 21, 27). It is generally accepted that the Froehlich equation (abutment scour) gives "excessively conservative estimates of scour depths" (Richardson and others, 1993, p. 48). Many factors, including historical performance during flood events, the geomorphic assessment, and the results of the hydraulic analyses, must be considered to properly assess the validity of abutment scour results. 


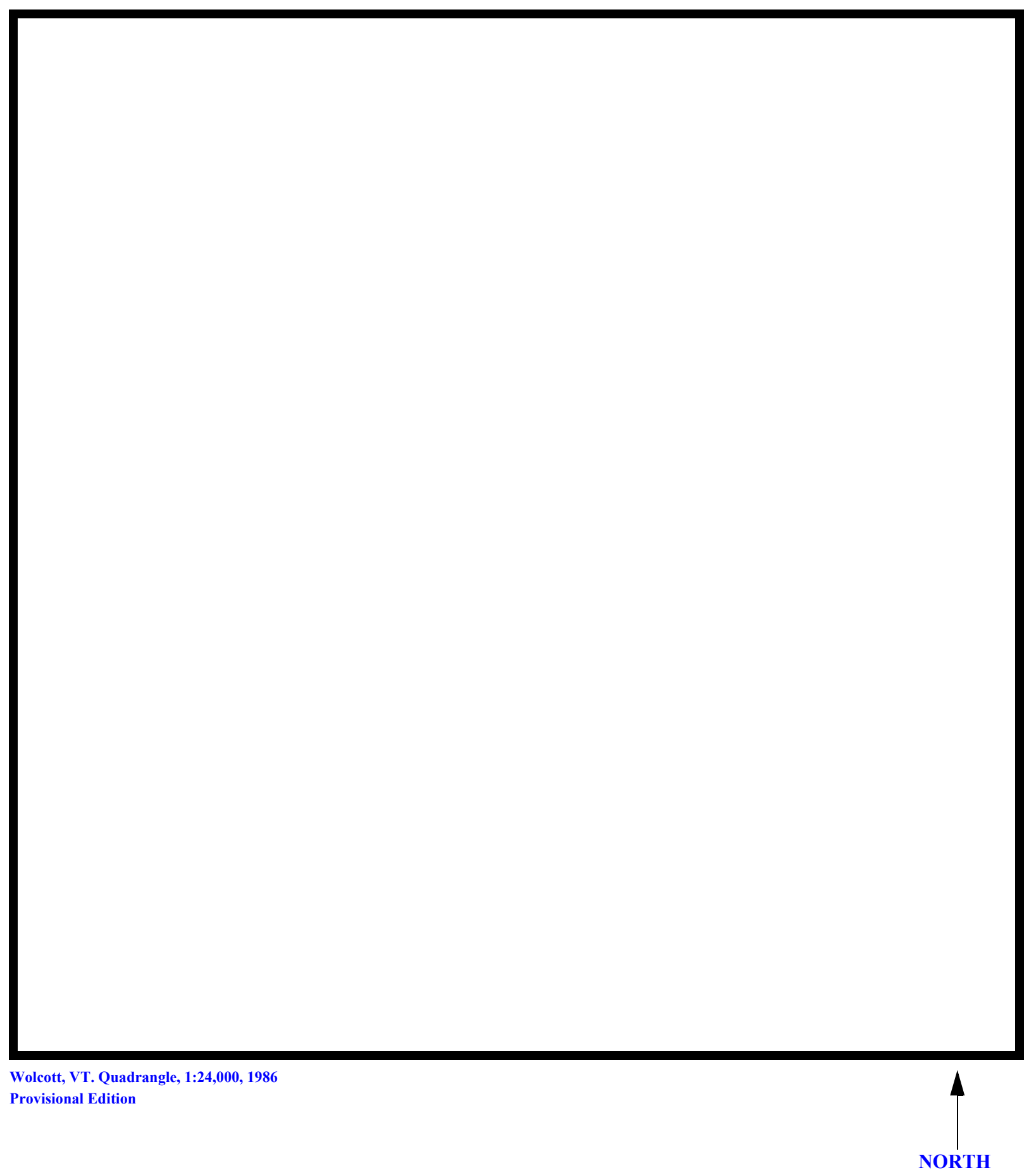

Figure 1. Location of study area on USGS 1:24,000 scale map. 
Figure 2. Location of study area on Vermont Agency of Transportation town highway map. 

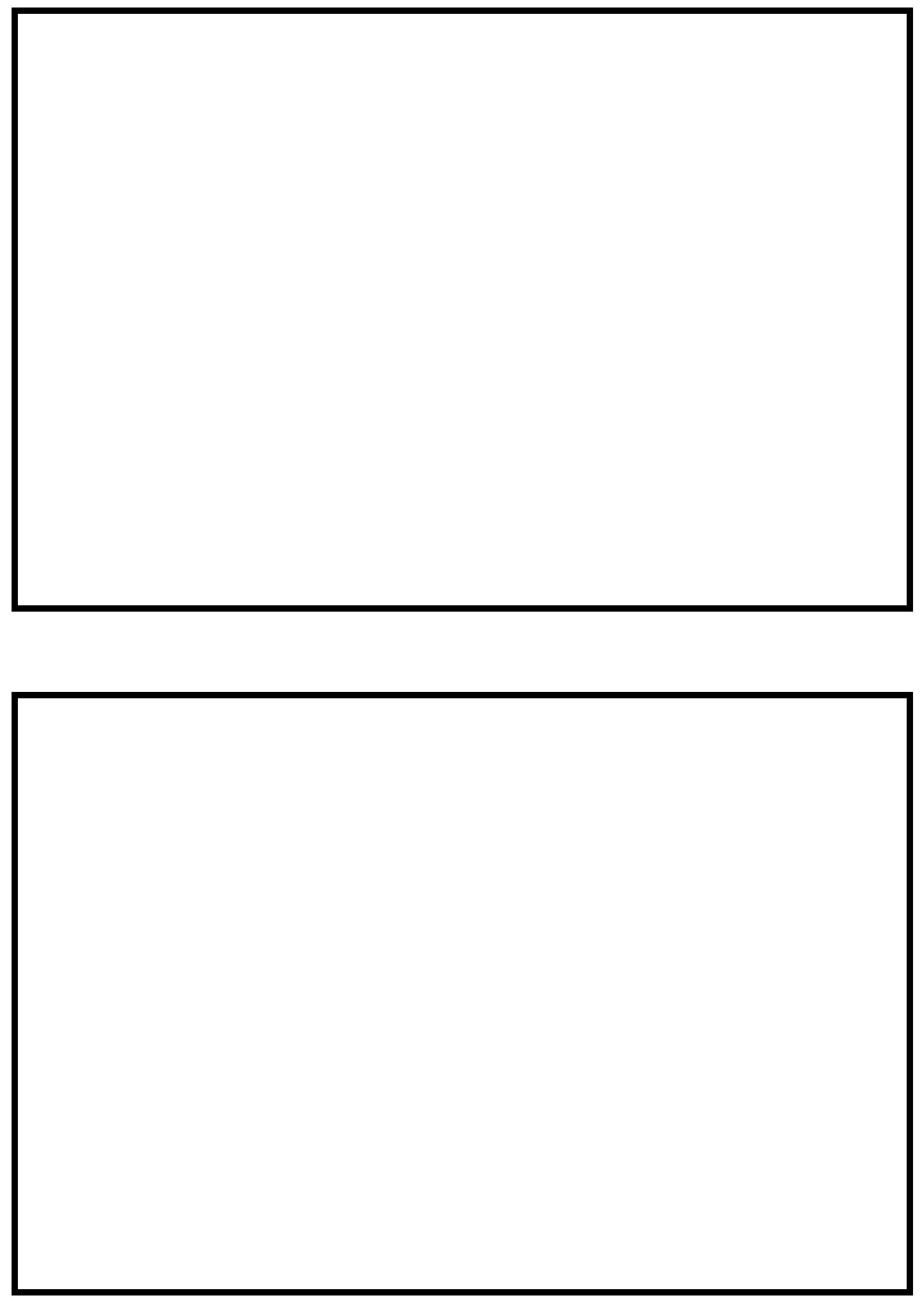

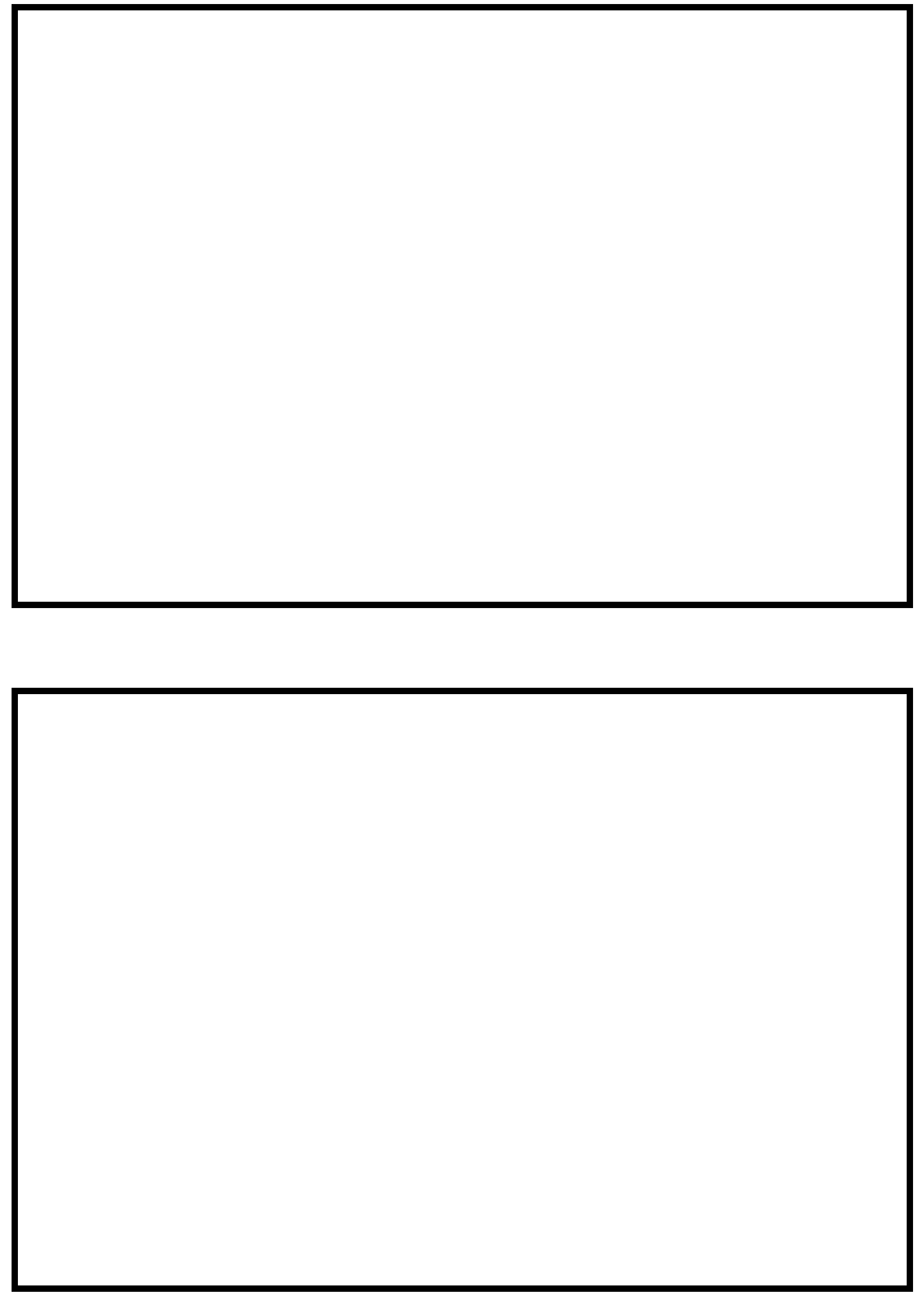


\section{LEVEL II SUMMARY}

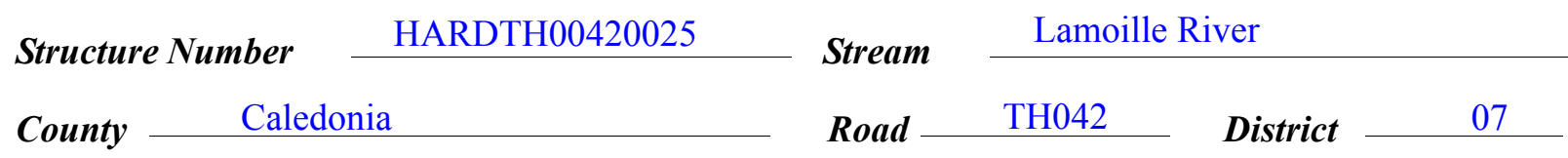

\section{Description of Bridge}

Bridge length $\frac{62}{6 t} \quad$ Bridge width $\stackrel{25.3}{f t}$ Max span length $\frac{60}{f t}$ Alignment of bridge to road (on curve or straight) vertical Abutment type

Stone fill on abutment? yes

\section{Embankment type} straight

Dasmintion af ata... n fill Type-2, in good condition; a second inspection was done on 08/16/95 sloping $07 / 25 / 95$ after a significant (greater than 100-yr) flood event and the condition of the stone fill was unchanged

Abutments and wingwalls are concrete $\ldots \ldots \ldots$

$\mathrm{N}$ Is bridge skewed to flood flow according to Y r survey? Angle (Opening skew to roadway is 0 degrees)

Debris accumulation on bridge at time of Level I or Level II site visit:

Date of incnortinn $07 / 25 / 95$

Level I

$07 / 27 / 95$

\section{Percent of alomnal blocked inorizontatly}

Percent of annel blocked verticatty

\section{Level II}

Moderate, due to woody vegetation on upstream left bank several hundred feet US of the structure

Potential for debris

There is a strong main-channel constriction in the approach to the bridge. Additionally the is a Doscriho anv, foaturos noar ar at tho hridos that mav, affoct flow, (includo ahsorvation dato) meander several hundred feet US and a localized, vegetated point bar that was noted on 07/25/95.

Relief is present as a low point in the left overbank of the roadway. 


\section{Description of the Geomorphic Setting}

General topography The bridge is in a $600 \mathrm{ft}$-wide, flat valley approx. $500 \mathrm{ft}$ DS of a major channel bend. Vermont Rte. 15 is adjacent to the north valley wall.

Geomorphic conditions at bridge site: downstream (DS), upstream (US)

Date of inspection $\quad 07 / 25 / 95$

DS left: $\quad$ wide (approx. $300 \mathrm{ft}$ ) flood plain

DS right: $\quad$ narrow terrace (VT Route 15) and steep valley wall

US left: $\quad$ wide (approx. $300 \mathrm{ft}$ ) flood plain

US right: narrow terrace (VT Route 15) and steep valley wall

\section{Description of the Channel}

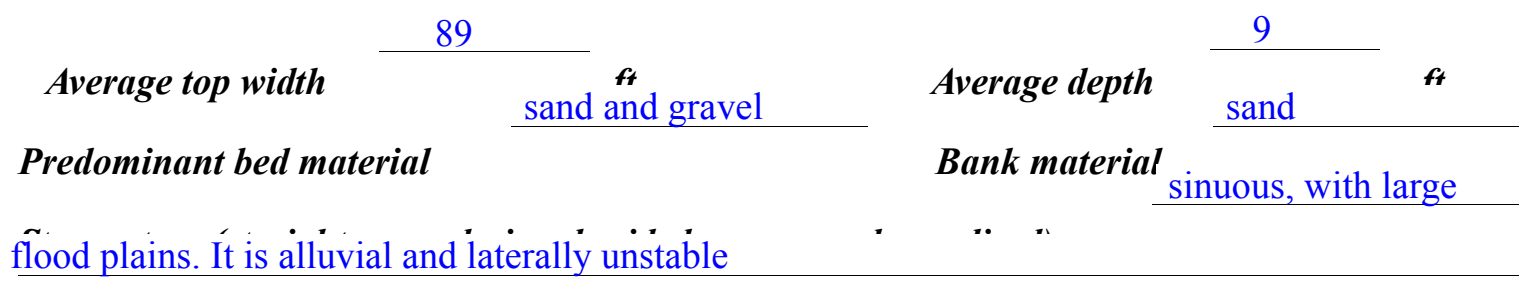

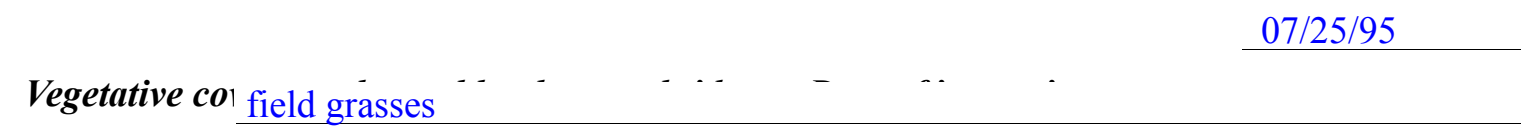

DS left: $\quad$ Vt Route 15

DS right: field grasses

US left: $\quad$ Vt Route 15

US right: $\quad \underline{\mathrm{N}}$

Do banks appear stable? 07/25/95--Both the left and right banks are reported to be eroded by means of moderate to heavy fluvial processes where there is no bank protection. The USRB is
date of observatton. eroded heavily due to flow impact; the USLB is more stable but is eroded in places; the DSLB has light fluvial erosion beyond the stone fill protection area.

07/25/95--No large obstructions; 08/16/95--Some minor debris reported at the base of the left abutment from a recent

flood event.

Describe any obstructions in channel and date of observation. 


\section{Hydrology}

Drainage area $\frac{119}{\boldsymbol{m i}^{2}}$

Percentage of drainage area in physiographic provinces: (approximate)

Physiographic province

Green Mountain Prov.
Percent of drainage area

100

Is drainage area considered rural or urban? Rural _ Describe any significant urbanization: None. Site is in an agricultural valley

Yes

Is there a USGS gage on the stream of interest? Lamoille at Johnson, Vermont

USGS gage description

04292000

\section{USGS gage number}

310

Gage drainage area $\quad \mathrm{mi}^{2}$

No

Is there a lake/p There is a concrete dam approx. $5000 \mathrm{ft} \mathrm{US}$ of the bridge but it is considered to have little effect on the hydrology or hydraulics at the site. Hardwick lake, $6000 \mathrm{ft}$ US of the bridge is also considered to have only minor effects.

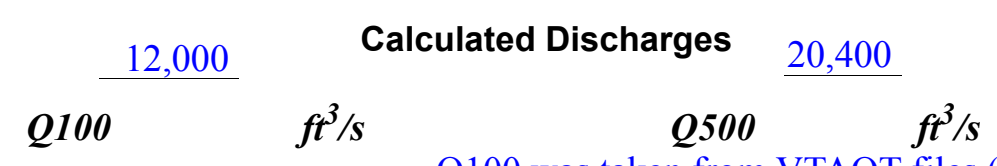
Q100 was taken from VTAOT files (Vermont

Agency of Transportation, written commun., March, 1995) . Q500 was determined by multiplying the Q100 by 1.7 


\section{Description of the Water-Surface Profile Model (WSPRO) Analysis}

Datum for WSPRO analysis (USGS survey, sea level, VTAOT plans)

USGS survey

Datum tie between USGS survey and VTAOT plans $\quad$ Subtract $0.11 \mathrm{ft}$ from USGS

datum to get VTAOT datum which is also NGVD 1929.

Description of reference marks used to determine USGS datum. $\quad$ RM1 is a chiseled X on

the DS end of the left abutment (arbitrary elev. 796.20). RM2 is a chiseled X on the US end of

the right abutment (arbitrary elev. 796.82). RM3 is a VTAOT brass survey disk on the top of the

US left wingwall (VTAOT elev. 796.10, USGS arbitrary elev. 796.21).

\section{Cross-Sections Used in WSPRO Analysis}

\begin{tabular}{|c|c|c|c|}
\hline${ }^{1}$ Cross-section & $\begin{array}{c}\text { Section } \\
\text { Reference } \\
\text { Distance } \\
\text { (SRD) in feet }\end{array}$ & $\begin{array}{c}{ }^{2} \text { Cross-section } \\
\text { development }\end{array}$ & Comments \\
\hline EXITX & -62 & 1 & Exit section \\
\hline FULLV & 0 & 2 & $\begin{array}{l}\text { Downstream Full-valley } \\
\text { section (Templated from } \\
\text { EXITX) }\end{array}$ \\
\hline BRIDG & 0 & 1 & $\begin{array}{l}\text { Upstream BRDGE face, } \\
\text { move to downstream face } \\
\text { (SRD is } 0 \text { ) }\end{array}$ \\
\hline RDWAY & 13 & 1 & Road Grade section \\
\hline APPRO & 68 & 1 & $\begin{array}{l}\text { Modelled Approach sec- } \\
\text { tion (Templated from } \\
\text { SURVA) }\end{array}$ \\
\hline SURVA & 105 & 1 & $\begin{array}{l}\text { Approach section as sur- } \\
\text { veyed (Used as a tem- } \\
\text { plate) }\end{array}$ \\
\hline
\end{tabular}

${ }^{1}$ For location of cross-sections see plan-view sketch included with Level I field form, Appendix E. For more detail on how cross-sections were developed see WSPRO input file. 


\section{Data and Assumptions Used in WSPRO Model}

Hydraulic analyses of the reach were done by use of the Federal Highway Administration's WSPRO step-backwater computer program (Shearman and others, 1986, and Shearman, 1990). The analysis reported herein reflects conditions existing at the site at the time of the study. Furthermore, in the development of the model it was necessary to assume no accumulation of debris or ice at the site. Results of the hydraulic model are presented in the Bridge Hydraulic Summary, Appendix B, and figure 7.

Channel roughness factors (Manning's " $n$ ") used in the hydraulic model were estimated using field inspections at each cross section following the general guidelines described by Arcement, Jr. and Schneider (1989). Final adjustments to the values were made during the modelling of the reach. Channel " $\mathrm{n}$ " values for the reach ranged from 0.030 to 0.040 , and the overbank " $n$ " value was 0.030 .

Normal depth at the exit section (EXITX) was assumed as the starting water surface. This depth was computed by use of the slope-conveyance method outlined in the User's manual for WSPRO (Shearman, 1990). The slope used was $0.0005 \mathrm{ft} / \mathrm{ft}$ which was estimated from the topographic map (U.S. Geological Survey, 1986).

The surveyed approach section (SURVA) was moved along the approach channel slope $(0.0005 \mathrm{ft} / \mathrm{ft})$ to establish the modelled approach section (APPRO), one bridge length upstream of the upstream face as recommended by Shearman and others (1986). This approach also provides a consistent method for determining scour variables.

The 100- and 500-year discharges significantly overtop the left road approach so the model was also run with a discharge of $3,840 \mathrm{ft}^{3} / \mathrm{s}$ which is at the incipient overtopping discharge elevation. 


\section{Bridge Hydraulics Summary}

\begin{tabular}{llll} 
Average bridge embankment elevation & 795.8 & $f t$ \\
\cline { 2 - 3 } Average low steel elevation & 791.5 & $\boldsymbol{f t}$
\end{tabular}

100-year discharge $\quad 12,000 \quad \mathrm{ft}^{3} / \mathrm{s}$

Water-surface elevation in bridge opening $\quad \begin{array}{lll}791.7 & f t\end{array}$

Road overtopping? __ Y Discharge over road $\quad 7299$, s

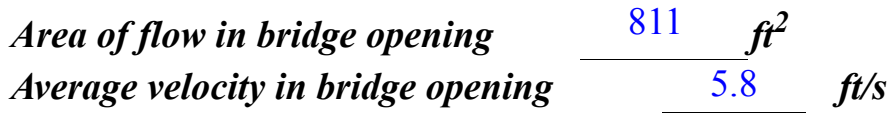

$\begin{array}{lll}\text { Maximum WSPRO tube velocity at bridge } & 6.9 \mathrm{ft} / \mathrm{s}\end{array}$

Water-surface elevation at Approach section with bridge 794.8

Water-surface elevation at Approach section without bridge

Amount of backwater caused by bridge

0.7 it

\section{1}

500-year discharge $\quad 20,400 \quad \mathrm{ft}^{3} / \mathrm{s}$

Water-surface elevation in bridge opening

Road overtopping? ___ Y Discharge over road _ $16343, \mathrm{~J} / \mathrm{s}$

Area of flow in bridge opening $\quad 811 \quad \boldsymbol{f t}^{2}$

Average velocity in bridge opening $5.4 \mathrm{ft} / \mathrm{s}$

Maximum WSPRO tube velocity at bridge 6.4 _'s

Water-surface elevation at Approach section with bridge 796.9

Water-surface elevation at Approach section without bridge $\quad 796.4$

Amount of backwater caused by bridge 0.5 .

Incipient overtopping discharge $\quad 3840 \quad \mathrm{ft}^{3} / \mathrm{s}$

Water-surface elevation in bridge opening $\quad 790 \quad$ t

Area of flow in bridge opening $\quad 725 \quad \mathrm{ft}^{\mathbf{2}}$

Average velocity in bridge opening $\quad 5.30 \quad \mathrm{ft} / \mathrm{s}$

Maximum WSPRO tube velocity at bridge $\quad 6.5 \mathrm{ft} / \mathrm{s}$

Water-surface elevation at Approach section with bridge

Water-surface elevation at Approach section without bridge

790.6

Amount of backwater caused by bridge $\quad . \quad$ it 


\section{Scour Analysis Summary}

\section{Special Conditions or Assumptions Made in Scour Analysis}

Scour depths were computed using the general guidelines described in Hydraulic Engineering Circular 18 (Richardson and others, 1993). Scour depths were calculated assuming an infinite depth of erosive material and a homogeneous particle-size distribution. The results of the scour analysis are presented in tables 1 and 2 and a graph of the scour depths is presented in figure 8.

The 100-year and 500-year discharges resulted in orifice flow and contraction scour was computed by use of the Chang equation (Richardson and others, 1995, p. 145-146). Contraction scour at bridges with orifice flow is best estimated by use of the Chang pressure-flow scour equation (oral communication, J. Sterling Jones, October 4, 1996). Contraction scour was computed by use of the clearwater contraction scour equation (Richardson and others, 1993, p. 35, equation 18) for the incipient roadoverflow discharge. For contraction scour computations, the average depth in the contracted section (AREA/TOPWIDTH) is subtracted from the depth of flow computed by the scour equation (Y2) to determine the actual amount of scour. None of the modelled flows resulted in contraction scour.

Abutment scour at the left abutment for all flows was computed using the HIRE equation (Richardson and others, 1993, p 50) because the HIRE equation is recommended when the length to depth ratio of the embankment blocking flow exceeds 25 . The length to depth ratio of the embankment blocking flow for the left abutment ranged from 131 to 265. The variables used by the HIRE abutmentscour equation include the Froude number of the flow approaching the embankments, the length of the embankment blocking flow, and the depth of flow approaching the embankment less any roadway overtopping. For the right abutment, the length to depth ratio of the embankment blocking flow ranged from 2.2 to 3.2 and the Froehlich equation (Richardson and others, 1993, p. 49, eq. 24) was used.

Post-flood scour was also measured on August 18, 1995 (after the August 5-6, 1995 flood) at this bridge. Observed contraction scour, determined by resurveying the pre-flood channel survey at the approach (APPRO) cross section, was less than $0.5 \mathrm{ft}$. For the SURVA cross section $105 \mathrm{ft}$ upstream of the bridge, approximately $1 \mathrm{ft}$ of scour was detected over a distance of $10 \mathrm{ft}$ near the left bank. Minor (approximately $1 \mathrm{ft}$ ) channel infilling was also detected near the pre-flood thalweg. Observed abutment scour, determined by resurveying the pre-flood channel survey at the bridge cross section, was less than $0.1 \mathrm{ft}$. Pre- and post-flood surveys of the above mentioned cross sections are shown in Appendix G. 


\section{Scour Results}

$$
\text { 100-yr discharge 500-yr discharge }
$$

(Scour depths in feet)

Main channel

Live-bed scour

Clear-water scour

Depth to armoring

Left overbank

Right overbank

Local scour:

Abutment scour

Left abutment

Right abutment

Pier scour

Pier 1

Pier 2

Pier 3
13.0

15.2
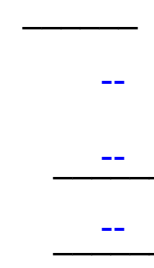

15.6

14.9-
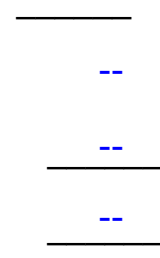

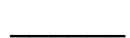

6.5

9.5-

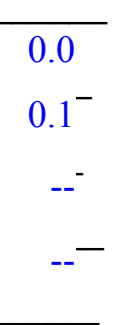

\section{Rock Riprap Sizing}

Incipient overtopping 100-yr discharge 500-yrdischarge discharge ( $D_{50}$ in feet)

Abutments:

Left abutment

0.6

0.6

Right abutment

Piers:

Pier 1

Pier 2
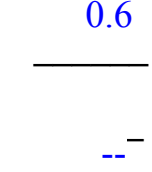

$--$

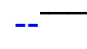

0.5
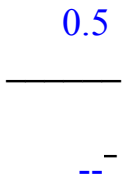

$-$

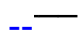

0.8

0.8 


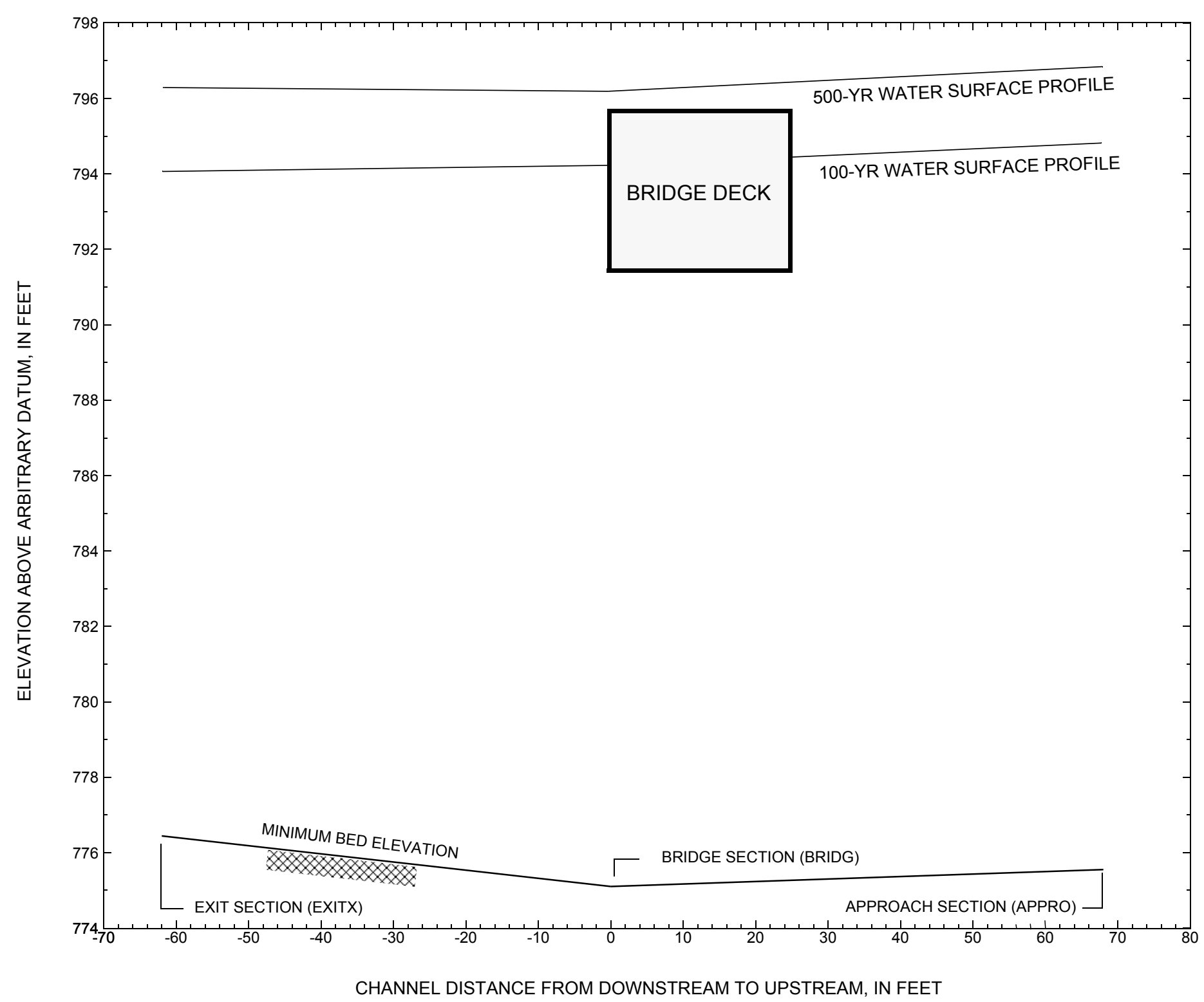

Figure 7. Water-surface profiles for the 100- and 500-yr discharges at structure HARDTH00420025 on town highway 42, crossing Lamoille River, Hardwick, Vermont. 


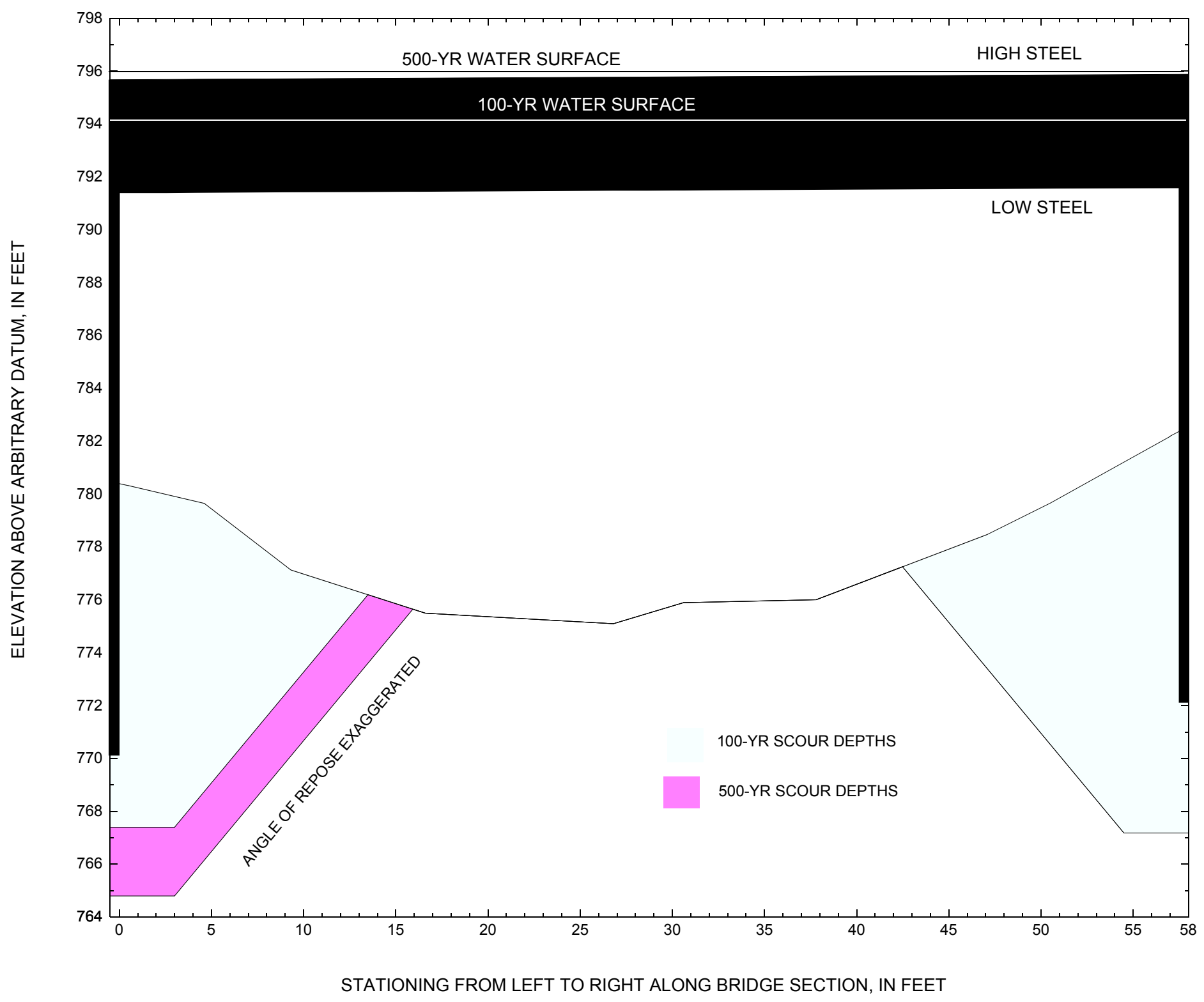

Figure 8. Scour elevations for the 100-yr and 500-yr discharges at structure HARDTH00420025 on town highway 42, crossing Lamoille River, Hardwick, Vermont. 
Table 1. Remaining footing/pile depth at abutments for the 100-year discharge at structure HARDTH00420025 on TOWN HIGHWAY 42, crossing Lamoille River, Hardwick, Vermont.

[VTAOT, Vermont Agency of Transportation; --,no data]

\begin{tabular}{|c|c|c|c|c|c|c|c|c|c|c|c|}
\hline Description & Station $^{1}$ & $\begin{array}{l}\text { VTAOT } \\
\text { minimum } \\
\text { low-chord } \\
\text { elevation } \\
\text { (feet) }\end{array}$ & $\begin{array}{c}\text { Surveyed } \\
\text { minimum } \\
\text { low-chord } \\
\text { elevation } \\
\text { (feet) }\end{array}$ & $\begin{array}{c}\text { Bottom of } \\
\text { footing } \\
\text { elevation } \\
\text { (feet) }\end{array}$ & $\begin{array}{c}\text { Channel } \\
\text { elevation at } \\
\text { abutment/ } \\
\text { pier }^{2} \\
\text { (feet) }\end{array}$ & $\begin{array}{l}\text { Contraction } \\
\text { scour depth } \\
\text { (feet) }\end{array}$ & $\begin{array}{l}\text { Abutment } \\
\text { scour } \\
\text { depth } \\
\text { (feet) }\end{array}$ & $\begin{array}{l}\text { Pier } \\
\text { scour } \\
\text { depth } \\
\text { (feet) }\end{array}$ & $\begin{array}{l}\text { Depth of } \\
\text { total scour } \\
\text { (feet) }\end{array}$ & $\begin{array}{c}\text { Elevation of } \\
\text { scour }^{2} \\
\text { (feet) }\end{array}$ & $\begin{array}{c}\text { Remaining } \\
\text { footing/pile } \\
\text { depth } \\
\text { (feet) }\end{array}$ \\
\hline \multicolumn{12}{|c|}{100 -yr. discharge is 12,000 cubic-feet per second } \\
\hline Left abutment & 0.0 & 791.1 & 791.3 & 770.1 & 780.4 & 0.0 & 13.0 & -- & 13.0 & 767.4 & -2.7 \\
\hline Right abutment & 57.5 & 791.7 & 791.7 & 772.1 & 782.4 & 0.0 & 15.2 & -- & 15.2 & 767.2 & -4.9 \\
\hline
\end{tabular}

1. Measured along the face of the most constricting side of the bridge.

2. Arbitrary datum for this study.

Table 2. Remaining footing/pile depth at abutments for the 500-year discharge at structure HARDTH00420025 on TOWN HIGHWAY 42, crossing Lamoille River, Hardwick, Vermont.

[VTAOT, Vermont Agency of Transportation; --, no data]

\begin{tabular}{|c|c|c|c|c|c|c|c|c|c|c|c|}
\hline Description & Station $^{1}$ & $\begin{array}{l}\text { VTAOT } \\
\text { minimum } \\
\text { low-chord } \\
\text { elevation } \\
\text { (feet) }\end{array}$ & $\begin{array}{l}\text { Surveyed } \\
\text { minimum } \\
\text { low-chord } \\
\text { elevation } \\
\quad \text { (feet) }\end{array}$ & $\begin{array}{l}\text { Bottom of } \\
\text { footing } \\
\text { elevation } \\
\text { (feet) }\end{array}$ & $\begin{array}{c}\text { Channel } \\
\text { elevation at } \\
\text { abutment/ } \\
\text { pier }^{2} \\
\text { (feet) }\end{array}$ & $\begin{array}{l}\text { Contraction } \\
\text { scour depth } \\
\text { (feet) }\end{array}$ & $\begin{array}{l}\text { Abutment } \\
\text { scour } \\
\text { depth } \\
\text { (feet) }\end{array}$ & $\begin{array}{l}\text { Pier } \\
\text { scour } \\
\text { depth } \\
\text { (feet) }\end{array}$ & $\begin{array}{l}\text { Depth of } \\
\text { total scour } \\
\text { (feet) }\end{array}$ & $\begin{array}{c}\text { Elevation of } \\
\text { scour }^{2} \\
\text { (feet) }\end{array}$ & $\begin{array}{l}\text { Remaining } \\
\text { footing/pile } \\
\text { depth } \\
\text { (feet) }\end{array}$ \\
\hline \multicolumn{12}{|c|}{500 -yr. discharge is 20,400 cubic-feet per second } \\
\hline Left abutment & 0.0 & 791.1 & 791.3 & 770.1 & 780.4 & 0.0 & 15.6 & -- & 15.6 & 764.8 & -5.3 \\
\hline Right abutment & 57.5 & 791.7 & 791.7 & 772.1 & 782.4 & 0.0 & 14.9 & -- & 14.9 & 767.5 & -4.6 \\
\hline
\end{tabular}

1. Measured along the face of the most constricting side of the bridge.

2. Arbitrary datum for this study. 


\section{SELECTED REFERENCES}

Arcement, G.J., Jr., and Schneider, V.R., 1989, Guide for selecting Manning's roughness coefficients for natural channels and flood plains: U.S. Geological Survey Water-Supply Paper 2339, 38 p.

Barnes, H.H., Jr., 1967, Roughness characteristics of natural channels: U.S. Geological Survey Water-Supply Paper 1849,213 p.

Brown, S.A. and Clyde, E.S., 1989, Design of riprap revetment: Federal Highway Administration Hydraulic Engineering Circular No. 11, Publication FHWA-IP-89-016, 156 p.

Federal Highway Administration, 1983, Runoff estimates for small watersheds and development of sound design: Federal Highway Administration Report FHWA-RD-77-158

Federal Emergency Management Agency, 1987, Flood Insurance Study, Town and Village of Hardwick, Caledonia County, Vermont, Washington, D.C., January 16, 1987.

Froehlich, D.C., 1989, Local scour at bridge abutments in Ports, M.A., ed., Hydraulic Engineering--Proceedings of the 1989 National Conference on Hydraulic Engineering: New York, American Society of Civil Engineers, p. 13-18.

Hayes, D.C.,1993, Site selection and collection of bridge-scour data in Delaware, Maryland, and Virginia: U.S. Geological Survey WaterResources Investigation Report 93-4017, 23 p.

Interagency Advisory Committee on Water Data, 1982, Guidelines for determining flood flow frequency: U.S. Geological Survey, Bulletin 17B of the Hydrology Subcommittee, 190 p.

Johnson, C.G. and Tasker, G.D.,1974, Progress report on flood magnitude and frequency of Vermont streams: U.S. Geological Survey OpenFile Report 74-130, 37 p.

Lagasse, P.F., Schall, J.D., Johnson, F., Richardson, E.V., Richardson, J.R., Chang, F., 1991, Stream Stability at Highway Structures: Federal Highway Administration Hydraulic Engineering Circular No. 20, Publication FHWA-IP-90-014, 195 p.

Laursen, E.M., 1960, Scour at bridge crossings: Journal of the Hydraulics Division, American Society of Civil Engineers, v. 86, no. HY2, p. $39-53$.

Potter, W. D., 1957a, Peak rates of runoff in the Adirondack, White Mountains, and Maine woods area, Bureau of Public Roads

Potter, W. D., 1957b, Peak rates of runoff in the New England Hill and Lowland area, Bureau of Public Roads

Richardson, E.V. and Davis, S.R., 1995, Evaluating scour at bridges: Federal Highway Administration Hydraulic Engineering Circular No. 18, Publication FHWA-IP-90-017, 204 p.

Richardson, E.V., Harrison, L.J., Richardson, J.R., and Davis, S.R., 1993, Evaluating scour at bridges: Federal Highway Administration Hydraulic Engineering Circular No. 18, Publication FHWA-IP-90-017, 131 p.

Richardson, E.V., Simons, D.B., and Julien, P.Y., 1990, Highways in the river environment: Federal Highway Administration Publication FHWA-HI-90-016.

Ritter, D.F., 1984, Process Geomorphology: W.C. Brown Co., Debuque, Iowa, 603 p.

Shearman, J.O., 1990, User's manual for WSPRO--a computer model for water surface profile computations: Federal Highway Administration Publication FHWA-IP-89-027, 187 p.

Shearman, J.O., Kirby, W.H., Schneider, V.R., and Flippo, H.N., 1986, Bridge waterways analysis model; research report: Federal Highway Administration Publication FHWA-RD-86-108, 112 p.

Talbot, A.N., 1887, The determination of water-way for bridges and culverts.

U.S. Department of Transportation, 1993, Stream stability and scour at highway bridges, Participant Workbook: Federal Highway Administration Publication FHWA HI-91-011.

U.S. Geological Survey, 1986, Wolcott, Vermont 7.5 Minute Series quadrangle map: U.S. Geological Survey Topographic Maps, Scale $1: 24,000$. 


\section{APPENDIX A: \\ WSPRO INPUT FILE}




\section{WSPRO INPUT FILE}

*

*

GR

GR

GR

*

GR

GR

GR

U.S. GEOLOGICAL SURVEY WSPRO INPUT FILE hard025.wSP CREATED ON 14-AUG-95 FOR BRIDGE HARDTH00420025 USING FILE hard025.dCa Hydraulic Analysis for HARD025 over Lamoille R. JDA

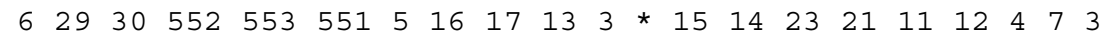

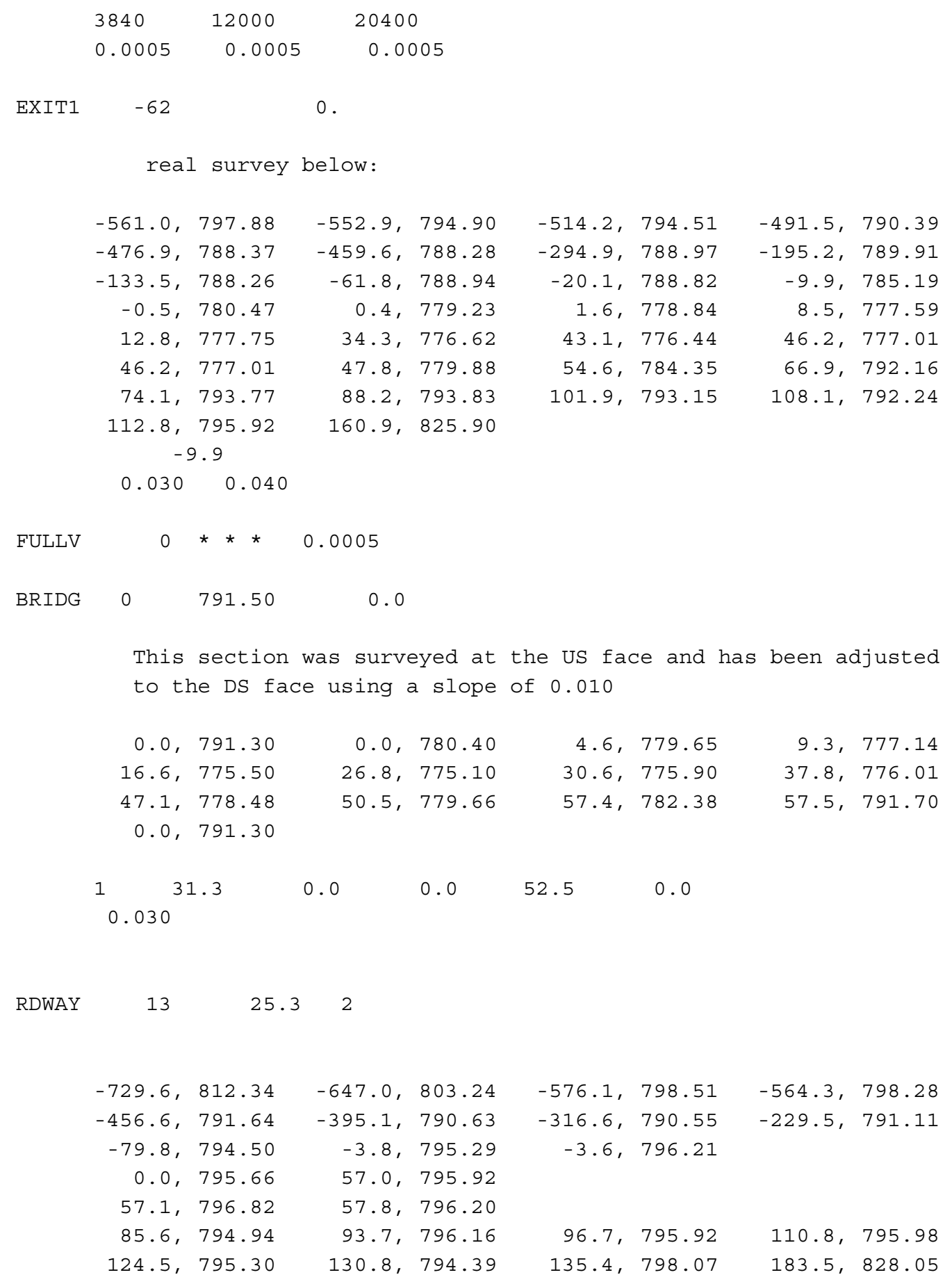


WSPRO INPUT FILE (continued)

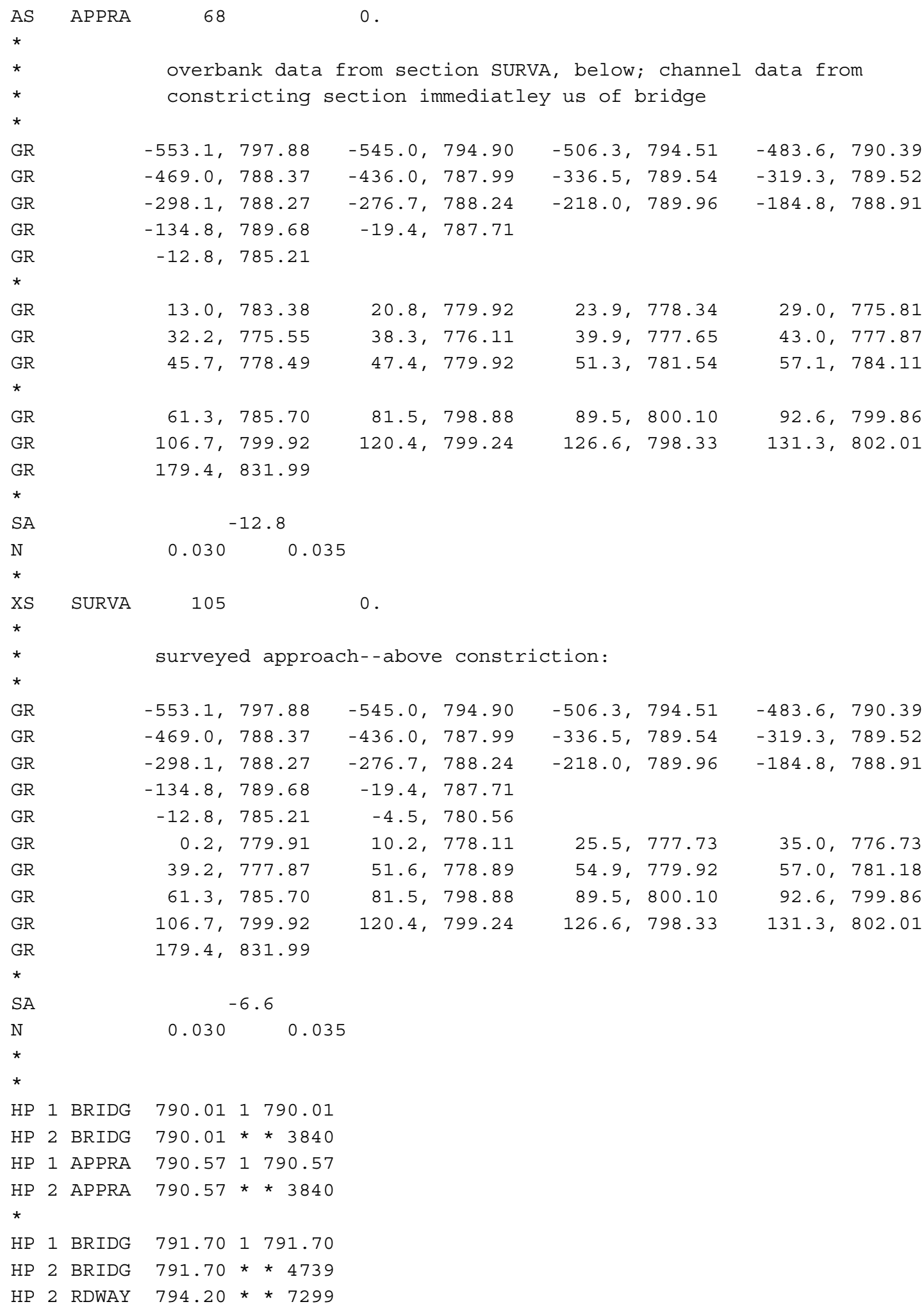




\section{APPENDIX B: \\ WSPRO OUTPUT FILE}




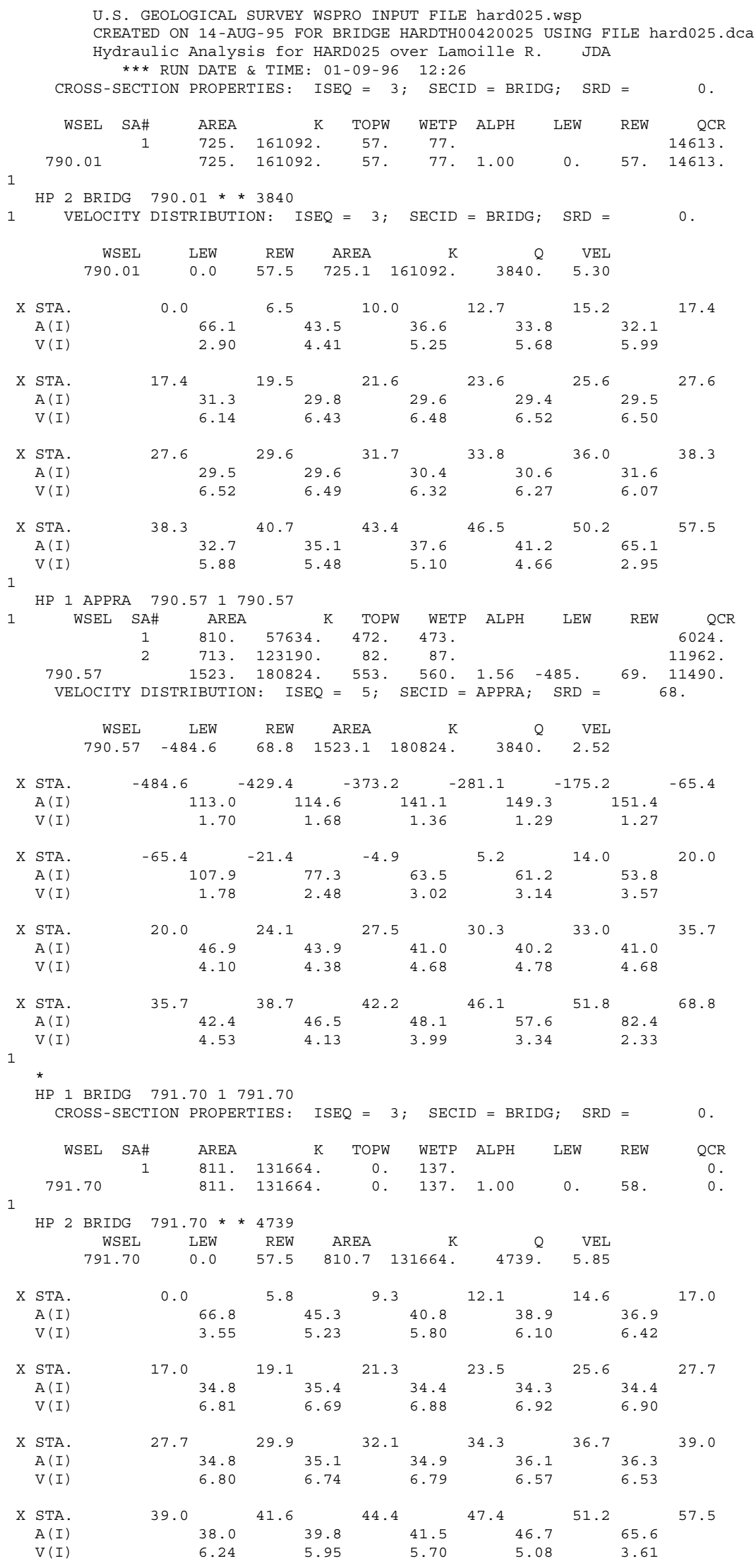




\section{WSPRO OUTPUT FILE (continued)}

HP 2 RDWAY 794.20 * * 7299

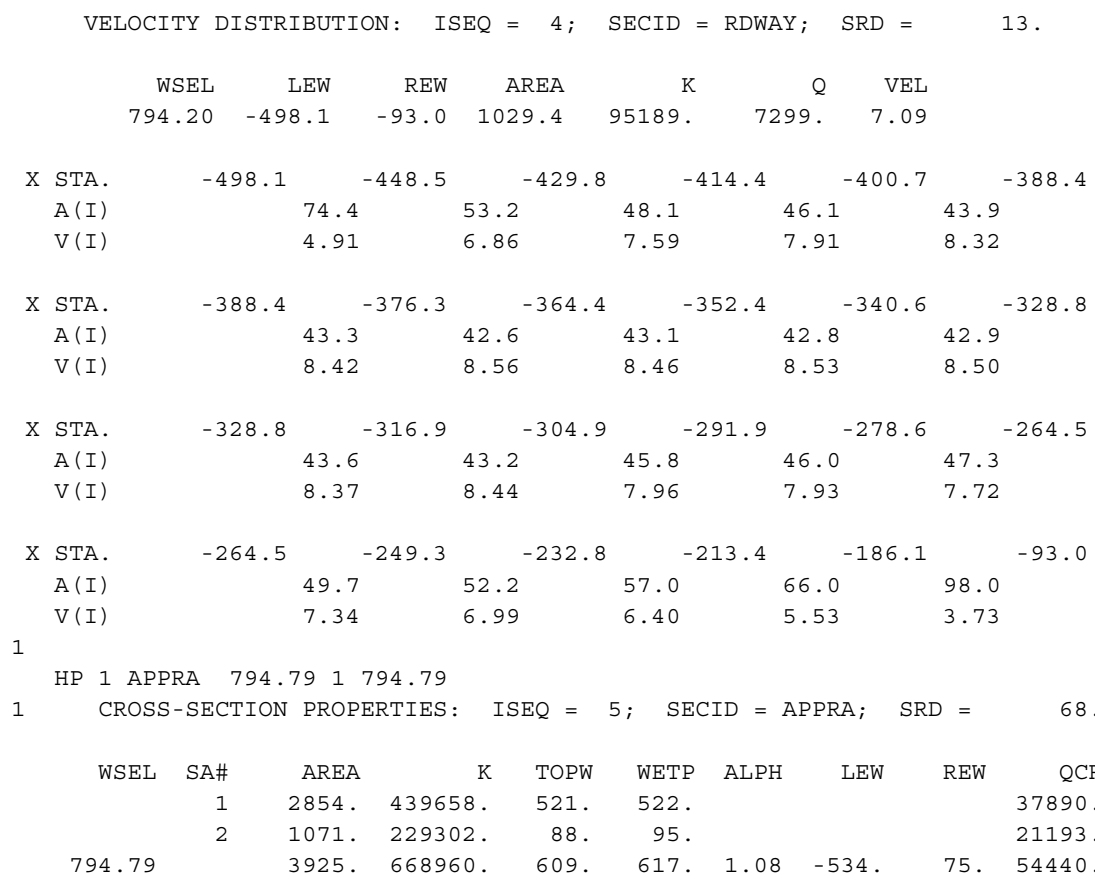

1

HP 2 APPRA 794.79* * 12000

VELOCITY DISTRIBUTION: ISEQ $=5 ; \operatorname{SECID~}=$ APPRA; $\operatorname{SRD}=68$.

$\begin{array}{rrrrrrr}\text { WSEL } & \text { LEW } & \text { REW } & \text { AREA } & \text { K } & Q & \text { VEL } \\ 794.79 & -534.1 & 75.2 & 3924.6 & 668960 . & 12000 . & 3.06\end{array}$

\begin{tabular}{|c|c|c|c|c|c|c|c|}
\hline \multirow[t]{3}{*}{$\mathrm{X}$} & STA. & -534.1 & -443.4 & -410.6 & -376.4 & -337.6 & -299.0 \\
\hline & $A(I)$ & 304.3 & 217.4 & 210.4 & 216.0 & \multicolumn{2}{|c|}{215.1} \\
\hline & $V(I)$ & 1.97 & 2.76 & 2.85 & 2.78 & \multicolumn{2}{|c|}{2.79} \\
\hline \multirow[t]{3}{*}{$\mathrm{X}$} & STA. & -299.0 & -268.4 & -232.1 & -188.5 & -150.8 & -108.0 \\
\hline & $A(I)$ & 199.0 & 209.9 & 227.3 & 212.6 & \multicolumn{2}{|c|}{226.5} \\
\hline & $\mathrm{V}(\mathrm{I})$ & 3.02 & 2.86 & 2.64 & 2.82 & \multicolumn{2}{|c|}{2.65} \\
\hline \multirow[t]{3}{*}{$\mathrm{X}$} & STA. & -108.0 & -73.0 & -42.2 & -15.4 & 1.8 & 15.8 \\
\hline & $A(I)$ & 205.2 & 198.4 & 188.2 & 170.6 & \multicolumn{2}{|c|}{157.3} \\
\hline & $V(I)$ & 2.92 & 3.02 & 3.19 & 3.52 & \multicolumn{2}{|c|}{3.81} \\
\hline $\mathrm{x}$ & STA. & 15.8 & 25.4 & 32.3 & 39.2 & 48.0 & 75.2 \\
\hline & $A(I)$ & 143.3 & 127.3 & 130.2 & 145.8 & & \\
\hline & $V(I)$ & 4.19 & 4.71 & 4.61 & 4.11 & & \\
\hline
\end{tabular}

1

HP 1 BRIDG 791.701791 .70

CROSS-SECTION PROPERTIES: ISEQ $=3 ;$ SECID $=$ BRIDG; $\quad$ SRD $=0$.

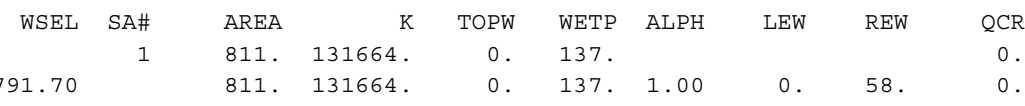

1

HP 2 BRIDG $791.70 *$ * 4372

VELOCITY DISTRIBUTION: ISEQ $=3 ;$ SECID $=$ BRIDG; $\quad$ SRD $=0$.

$\begin{array}{rrrrrrr}\text { WSEL } & \text { LEW } & \text { REW } & \text { AREA } & \text { K } & Q & \text { VEL } \\ 791.70 & 0.0 & 57.5 & 810.7 & 131664 . & 4372 . & 5.39\end{array}$

\begin{tabular}{|c|c|c|c|c|c|c|c|}
\hline $\mathrm{x}$ & STA. & 0.0 & 5.8 & 9.3 & 12.1 & 14.6 & 17.0 \\
\hline & $A(I)$ & 66.8 & 45.3 & 40.8 & 38.9 & & \\
\hline & $V(I)$ & 3.27 & 4.82 & 5.35 & 5.63 & & \\
\hline $\mathrm{X}$ & STA. & 17.0 & 19.1 & 21.3 & 23.5 & 25.6 & 27.7 \\
\hline & $A(I)$ & 34.8 & 35.4 & 34.4 & 34.3 & & \\
\hline & $\mathrm{V}(\mathrm{I})$ & 6.29 & 6.18 & 6.35 & 6.38 & & \\
\hline
\end{tabular}




\section{WSPRO OUTPUT FILE (continued)}

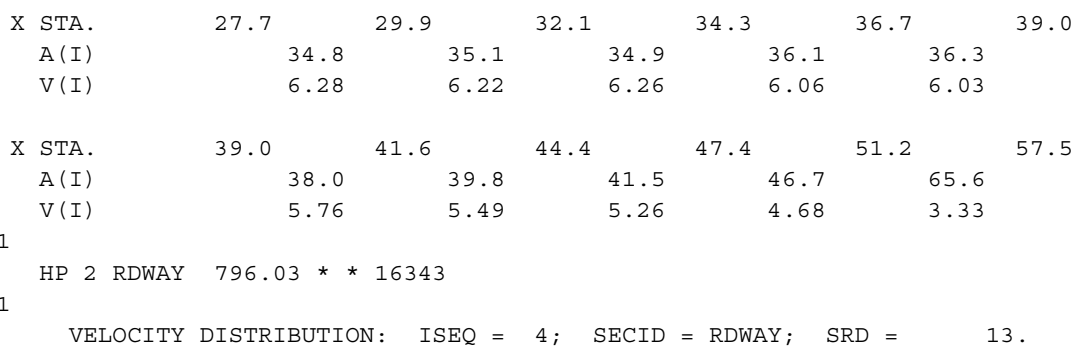


WSPRO OUTPUT FILE (continued)

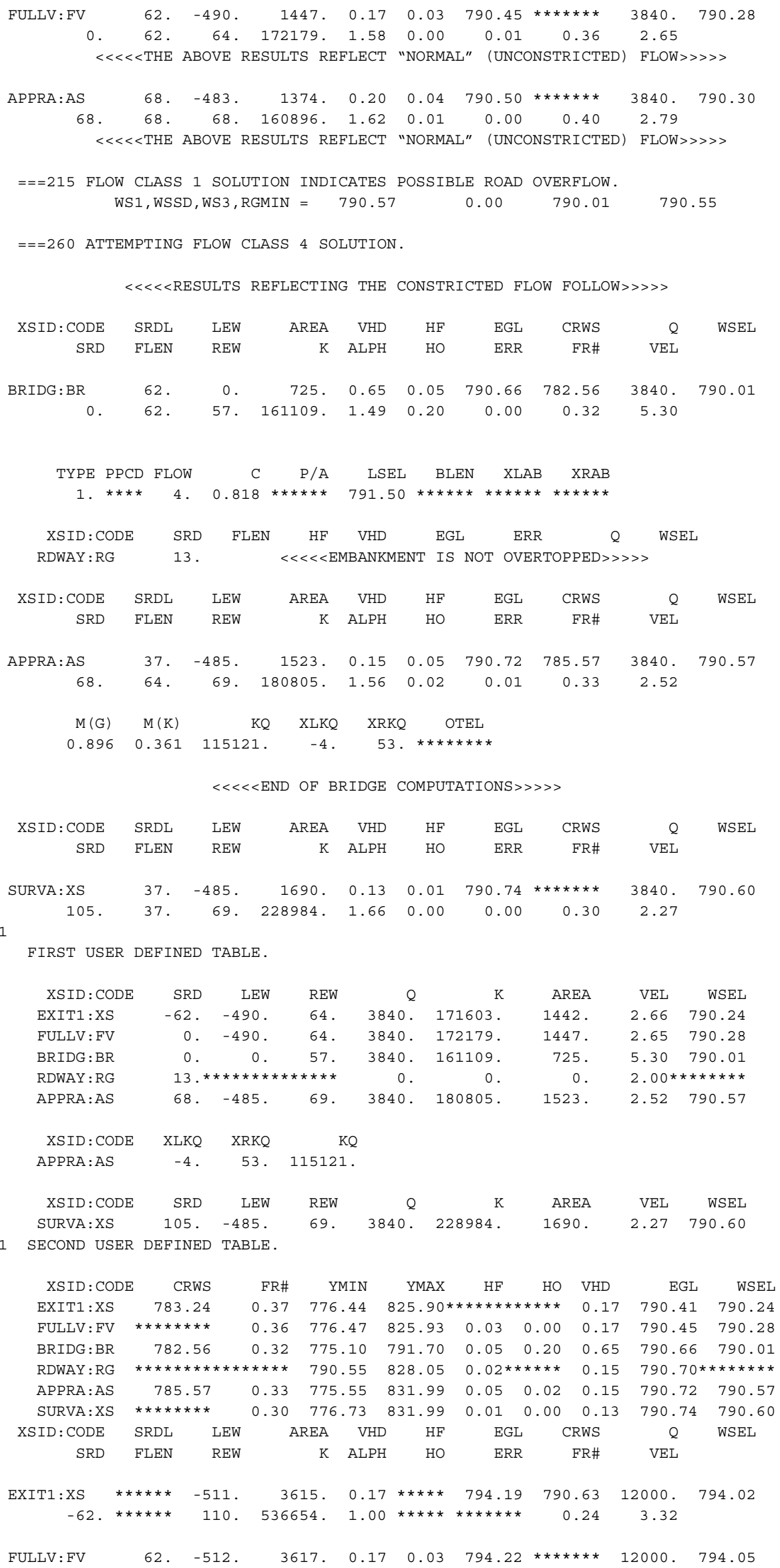


WSPRO OUTPUT FILE (continued)

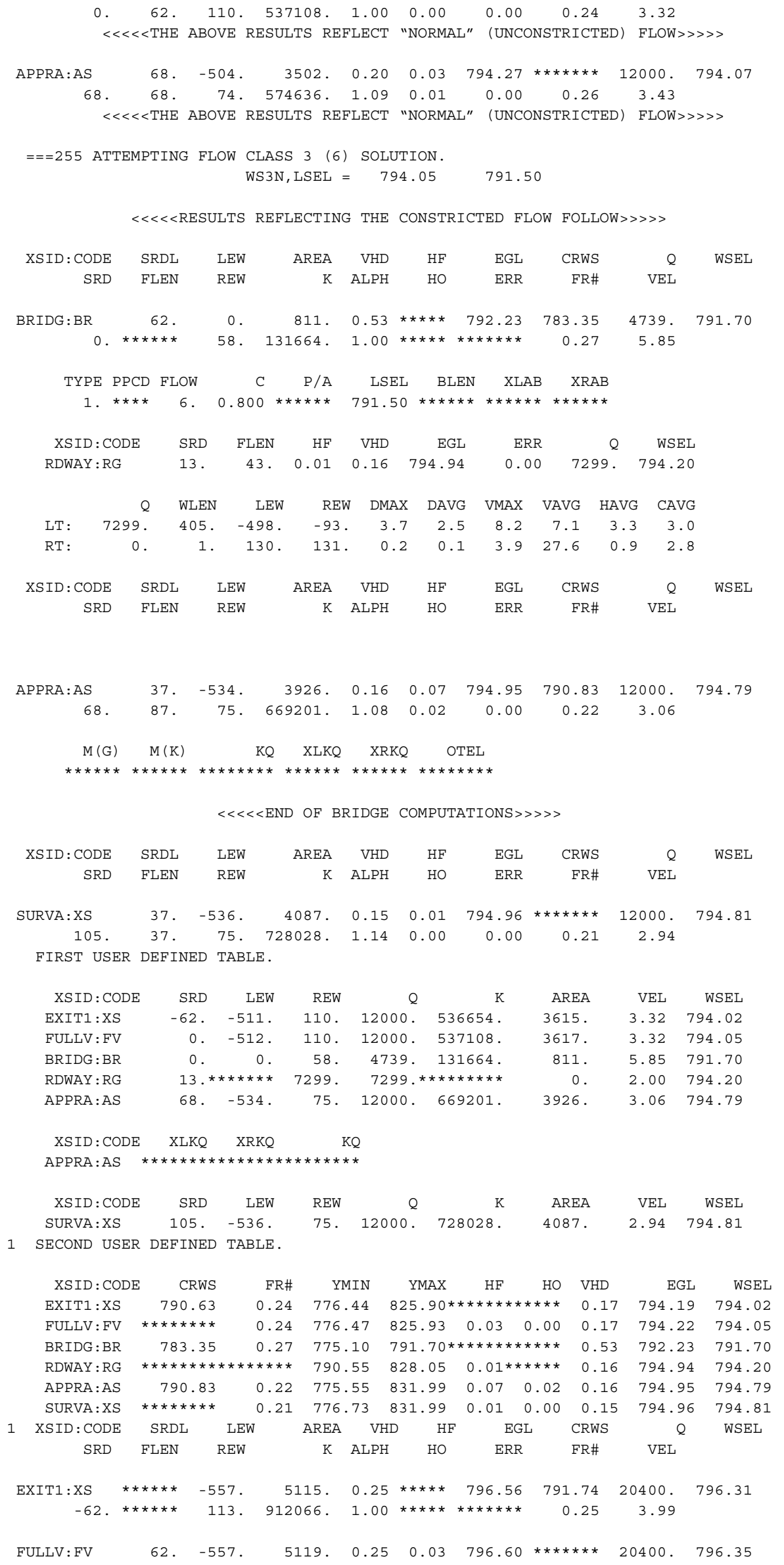


WSPRO OUTPUT FILE (continued)

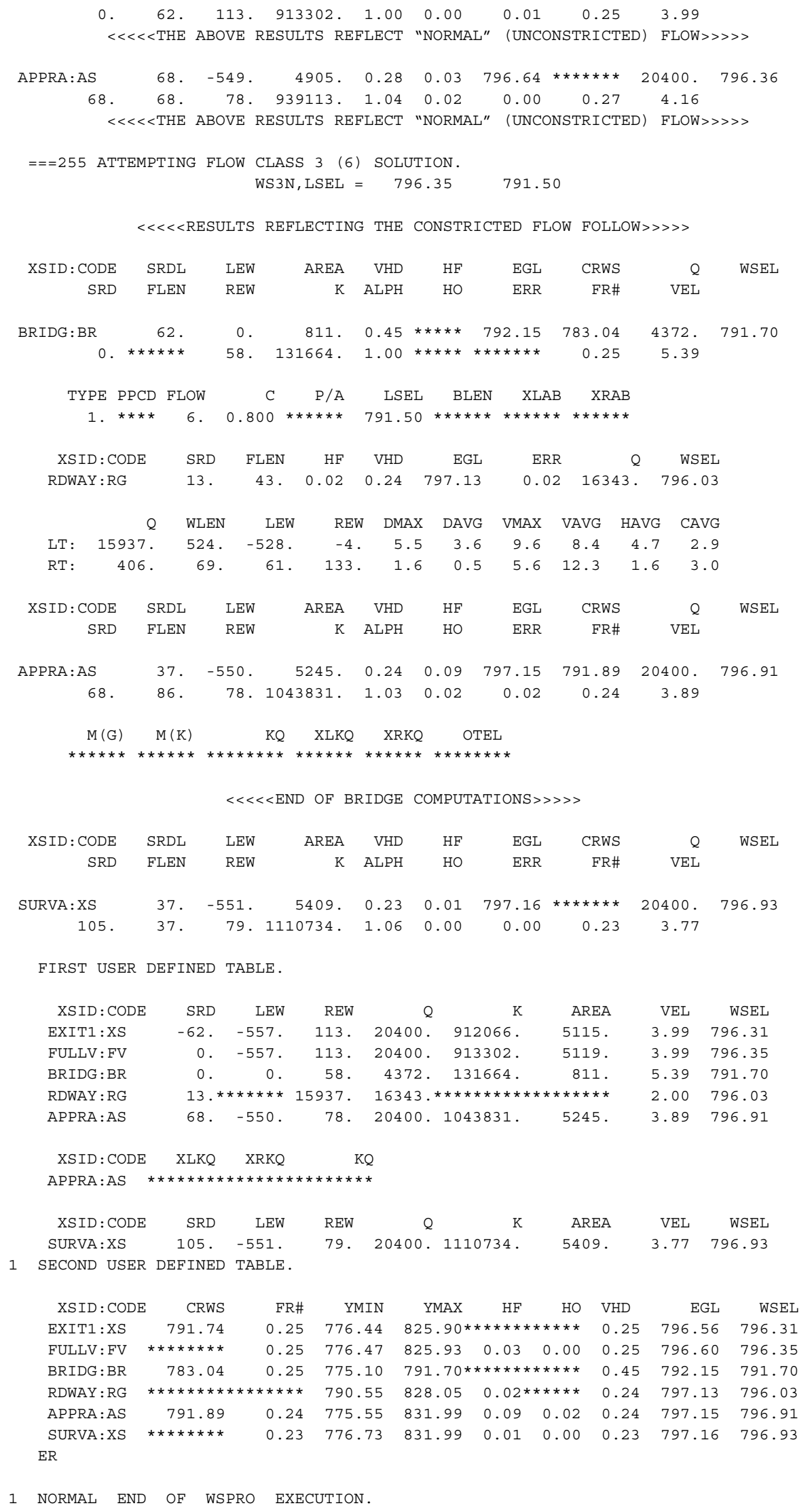




\section{APPENDIX C:}

\section{BED-MATERIAL PARTICAL-SIZE DISTRIBUTION}




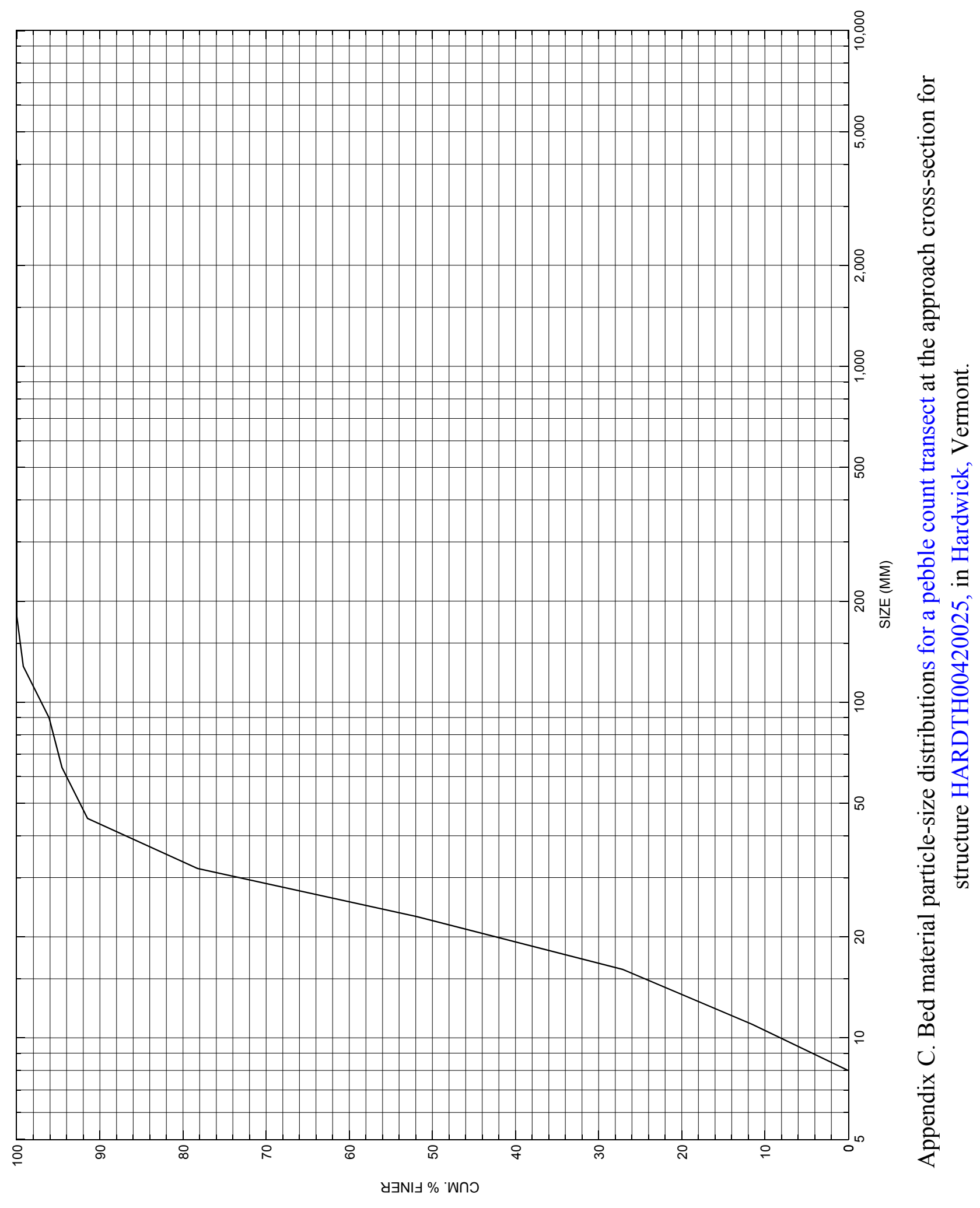




\section{APPENDIX D: \\ HISTORICAL DATA FORM}

